\title{
ENSO and IOD teleconnections for African ecosystems: evidence of destructive interference between climate oscillations
}

\author{
C. A. Williams ${ }^{1}$ and N. P. Hanan ${ }^{2}$ \\ ${ }^{1}$ Graduate School of Geography, Clark University, 950 Main Street, Worcester, Massachusetts 01610, USA \\ ${ }^{2}$ The Geographic Information Science Center of Excellence (GIScCE), South Dakota State University, Brookings, South \\ Dakota 57007, USA
}

Received: 12 July 2010 - Published in Biogeosciences Discuss.: 25 August 2010

Revised: 9 December 2010 - Accepted: 10 December 2010 - Published: 4 January 2011

\begin{abstract}
Rainfall and vegetation across Africa are known to resonate with the coupled ocean-atmosphere phenomena of El Niño Southern Oscillation (ENSO) and the Indian Ocean Dipole (IOD). However, the regional-scale implications of sea surface temperature variability for Africa's photosyntheis have received little focused attention, particularly in the case of IOD. Furthermore, studies exploring the interactive effects of ENSO and IOD when coincident are lacking. This analysis uses remotely sensed vegetation change plus a land surface model driven with observed meteorology to investigate how rainfall, vegetation, and photosynthesis across Africa respond to these climate oscillations. In addition to the relatively well-known ENSO forcing, the IOD induces large departures of photosynthesis across much of Africa associated with anomalies in rainfall and vegetation greenness. More importantly, sizeable independent effects can be suppressed or even reversed by destructive interferences during periods of simultaneous ENSO and IOD activity. For example, effects of positive IOD on southeastern Africa tended to dominate those of El Niño during their coincidence spanning 1997-1998, with sign reversal of El Niño's typically strong suppression of photosynthesis in this region. These findings call into question past analyses examining teleconnections to ENSO or IOD in isolation, and indicate the need to consider their simultaneous states when examining influences on hydroclimatic and ecological conditions across Africa.
\end{abstract}

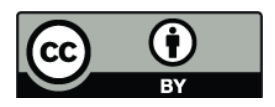

Correspondence to: C. A. Williams (cwilliams@clarku.edu)

\section{Introduction}

Most of the interannual variability in Africa's carbon cycle is caused by hydrologic fluctuations, particularly rainfall (Patra et al., 2005; Rödenbeck et al., 2003; van der Werf et al., 2006; Williams et al., 2007, 2008). This derives from the prevalence of water deficits in the extensive seasonal and semi-arid biomes of Africa (Nemani et al., 2003; Williams et al., 2008) compounded by sizeable year-to-year variability in rainfall (Nicholson and Kim, 1997; Nicholson, 2000, 2001; Tyson, 1980, 1991; Tyson et al., 2002). Temporal variability of Africa's rainfall resonates with the coupled ocean-atmosphere phenomena of El Niño Southern Oscillation (ENSO) and the Indian Ocean Dipole Zonal Mode (abbreviated here as IOD), but the degree to which these oscillations excite carbon cycle anomalies across Africa remains unclear, as are their interactive effects.

ENSO is a leading mode of tropical climate variability at interannual timescales and is characterized by sea surface temperature (SST) and surface pressure anomalies across the Pacific Ocean. Its positive "El Niño" phase occurs when SSTs are warm in the eastern tropical Pacific Ocean contrasted by its negative "La Niña" phase when they are cool. ENSO impacts on Africa are believed to occur in part via tropical Atlantic (Chiang and Sobel, 2002) and Indian Ocean (Alexander et al., 2002) teleconnections.

The IOD is another coupled ocean-atmosphere mode (Saji et al., 1999), with a positive (negative) phase characterized by warm (cool) SSTs over the western Indian Ocean and cool (warm) SSTs in the eastern Indian Ocean. Originally described as a dipole phenomenon, the Indian Ocean Dipole is reportedly rather a zonal mode instead, with the apparent dipole oscillation linked mostly to eastern Indian Ocean SSTs (Annamalai et al., 2003; Hong et al., 2008a, b) though still captured by the Saji et al. (1999) Dipole Mode Index.

Published by Copernicus Publications on behalf of the European Geosciences Union. 
In this paper we refer to the phenomenon as IOD akin to IOZM and IODZM used elsewhere. Though once questioned (Allan et al., 2001; Dommenget and Latif, 2002), several studies have defended statistical and dynamical independence of IOD from ENSO as a separate mode of variability (Behera et al., 2003; Behera and Yamagata, 2003; Fischer et al., 2005; Yamagata et al., 2003). Some even argue that the Indian Ocean influences the timing and intensity of ENSO (Annamalai et al., 2005; Wu and Kirtman, 2004). Though not the focus of study in this work, it is important to acknowledge other noteworthy phenomena driving regionally-important climate variability across Africa including the Benguela Niño (Boyer et al., 2000; Shannon et al., 1986), tropical Atlantic interdecadal oscillations (Giannini et al., 2003; Paz et al., 2003; Tourre et al., 1999, 2006), and an equatorial, quasi-biennial Atlantic SST oscillation (Balas et al., 2007; Giannini et al., 2003; Hirst and Hastenrath, 1983; Latif and Groetzner, 2000; Tourre et al., 1999; Zebiak, 1993).

Widespread observational evidence links African rainfall to ENSO and IOD. Examples come from continental analysis of gauge records (Nicholson and Kim, 1997; Nicholson, 2000, 2001) as well as more regional examinations in eastern (Birkett et al., 1999; Black et al., 2003; Black, 2005; Mapande and Reason, 2005; Marchant et al., 2007), western (Balas et al., 2007; Hirst and Hastenrath, 1983; Tourre et al., 2006) and southern Africa (Hachigonta and Reason, 2006; Reason, 2001, 2002; Saji and Yamagata, 2003; Todd and Washington, 1998; Usman and Reason, 2004). Additionally, rainwater isotopic composition in east Africa (Vuille et al., 2005), continent-wide river discharge (Dube and Jury, 2003; Jury, 2003), dust production (Bryant et al., 2007; Prospero and Nees, 1986), and even the chemical composition of coral (Kayanne et al., 2006; Zinke et al., 2004) all indicate resonance of African rainfall with these ocean-atmosphere modes of variability.

Corresponding changes in African vegetation induced by ENSO have been documented by analysis of satellite-derived normalized difference vegetation index (NDVI) (Anyamba and Eastman, 1996; Anyamba et al., 2001; Anyamba and Tucker, 2005; Ingram and Dawson, 2005; Philippon et al., 2007), but the same analysis has not been performed for the IOD. Furthermore, the regional-scale implications of SST variability for Africa's carbon sources and sinks have received little focused attention particularly in the case of IOD.

ENSO is a well-known driver of global-scale interannual variability in sources and sinks of $\mathrm{CO}_{2}$, particularly in the tropics (Bacastow, 1976; Jones et al., 2001; Rödenbeck et al., 2003). Much of the tropical response is now thought to be associated with fire emissions (Patra et al., 2005; van der Werf et al., 2006), but in the case of Africa, fire emissions exhibit relatively little interannual variability despite the continent's enormous fraction of the global pyrogenic release (van der Werf et al., 2004; Williams et al., 2007). Interannual variability is also thought to be slight for the continent's net land use flux of $\mathrm{CO}_{2}$ (Houghton, 2000). This implies that most of Africa's interannual variability in net ecosystem exchange is attributed to the balance of photosynthesis and respiration. Though ENSO-driven anomalies of Africa's photosynthesis have been coarsely examined before (Bacastow, 1976; Ciais et al., 2009; Jones et al., 2001; Rödenbeck et al., 2003), in this study we more closely analyze causes and detailed spatial patterns. This is also the first study to examine the degree to which Africa's regional to continental photosynthesis is also coupled to IOD. Furthermore, though ENSO and IOD events often coincide, little is known about how this modifies teleconnections typical of independent events.

Ecosystem process models are well suited for such examinations, being mechanistically based and applicable at a scale needed to resolve the sometimes complicated patterns of source/sink dynamics as they respond to variations in climate, soils and land use. Models guided by observed vegetation change and weather may be most appropriate for quantifying the degree to which climate fluctuations perturb ecosystem-atmosphere fluxes of water and carbon.

In this work we drive a land surface process model with historical weather and vegetation and analyze the connection of resultant photosynthesis patterns to remote sea surface temperature indices. We address the following questions:

- To what degree is photosynthesis across Africa coupled to ENSO and IOD?

- Where is this coupling strongest?

- What processes drive observed anomalies of photosynthesis?

- Is there evidence of interactions between ENSO and IOD influences?

Our analysis aims to unravel the independent and joint relationships between these climate modes and photosynthesis to elucidate how elements of Africa's carbon cycle are coupled to climate variability. We hope to clarify mechanisms that link land surface carbon and water balances to variability in the climate system. If observed associations between climate indices and productivity have predictive skill they may be useful for early warning and decision support to mitigate drought and related food scarcity, insect pest and disease vector outbreaks, and climate-related disasters.

\section{Methods}

The Simple Biosphere model, Version 3 (SiB3) was run for the period 1982 through 2003 with a 10-min time step on a $1^{\circ}$ by $1^{\circ}$ latitude/longitude grid. SiB is a land surface model originally designed (Sellers et al., 1986) for use with General Circulation Models but used here in an "offline" mode to represent ecosystem physiology as driven by weather (NCEP Reanalysis II with rainfall adjusted to satellite or gauge based records) and vegetation (represented with satellite-derived 
vegetation index). In this work we primarily analyze the model's canopy-scale net photosynthesis. Appendix A describes the model and implementation in greater detail and a companion paper, Williams et al. (2008), provides detailed assessment of acute stress and vegetation structural limits to photosynthesis across Africa.

To represent ENSO we use the Multivariate ENSO Index (MEI) of Wolter (1993) and Wolter and Timlin (1998) calculated from a principal components analysis of pressure, wind, and temperature fields in the equatorial Pacific Ocean. Positive index anomalies correspond to the warm phase (El Niño) contrasted with cold phase (La Niña) negative anomalies, and both tend to peak in boreal Fall to Winter. For the IOD we use the Indian Ocean Dipole Mode Index (DMI) of Saji et al. (1999) based on monthly sea surface temperatures from the technique in Kaplan et al. (1998) and reported with units of degrees Celsius. We z-score normalize the DMI to match the MEI's scale of standardized departures, which represent the number of standard deviations away from a mean of zero according to $Z_{t}=\frac{x_{i}-\bar{x}}{\sigma_{x}}$. The IOD (i.e. DMI) is calculated from the difference in sea surface temperature (SST) anomaly between the tropical western Indian Ocean and the tropical south-eastern Indian Ocean. Its positive phase peaks in September-October has warm SSTs over the western basin and cool SSTs off Sumatra (Murtugudde and Busalacchi, 1999; Saji et al., 1999). The positive phase SST anomalies can be accompanied by above average rainfall in eastern Africa and the tropical western Indian Ocean and diminished rainfall over Indonesia and the tropical southeastern Indian Ocean (Saji et al., 1999; Webster et al., 1999).

Analyses in this paper primarily involve the study of temporally and spatially composited anomalies of rainfall, vegetation, and net photosynthesis. Cell-specific time series are linearly detrended with removal of the 22-year trend (1982-2003) and aggregated into 3-month climatic season averages corresponding to climatic seasons: December-January-February (DJF), March-April-May (MAM), June-July-August (JJA), and September-OctoberNovember (SON). Anomaly time series are calculated as departures from the climatic season average. Temporal composites are produced from averaging anomaly time series across phase- and climatic season-specific events that represent each cell's average response to El Niño, La Niña, positive IOD, and negative IOD events. Phase-specific composites are further discretized into "pure" and "coincident" populations based on whether they do not or do coincide with activity in the other index (e.g. a coincident El Niño cooccurs with a positive or negative IOD event). Positive (negative) phase ENSO events are defined as those for which the MEI is equal to or exceeds (is lower than) the upper (lower) fifth of the MEI during the period under examination (1982 through 2003). The same approach defines positive and negative IOD events according to the DMI. These cell-specific, temporally-composited anomalies are spatially aggregated to geographic regions of similar ecoclimatic conditions to high- light regional tendencies and reduce the data dimension. We employ various statistical tests to assess the presence of significant relationships and differences including analysis of variance (ANOVA), and two-sample t-tests.

\section{Results and discussion}

\subsection{Continental patterns}

\subsubsection{ENSO Associations}

Net photosynthesis is strongly coupled to both phases of the Multivariate El Niño Southern Oscillation Index (i.e. ENSO) in regionally coherent spatial patterns across much of the African continent (Fig. 1a, Table 1). A general pattern of negative correlation between net photosynthesis and ENSO occurs across much of southern Africa with the strongest relationships near the Limpopo River in parts of Zimbabwe and Mozambique (Fig. 1a). Positive correlation is widespread across east-central Africa, mainly the seasonal forests and savannas of south-eastern Democratic Republic of Congo (DRC), Tanzania, and Kenya, and the Rift Valley highlands of Uganda, Rwanda and Burundi. Net photosynthesis anomalies across the Sahelian zone to the south of the Sahara Desert tend to be small with modest exceptions in southern Chad and Sudan mainly during JJA and SON. This finding agrees with previous reports of weak negative to no ENSO response of rainfall and NDVI for the Sahel (Anyamba and Eastman, 1996; Anyamba et al., 2001; Anyamba and Tucker, 2005; Nicholson and Kim, 1997; Philippon et al., 2007). Sizeable MAM and JJA sensitivities are evident for coastal West Africa contrasting a positive relation in Sierra Leone and Guinea with negative relations to the east in Cote d'Ivoire and Ghana, and to the north in Senegal, Gambia, and southern Mauritania.

Regional relationships to ENSO can shift seasonally (Figs. 1a, 2, Table 1). For example, in southern Africa prevailing suppression of photosynthesis in DJF and MAM El Niño events is at odds with SON enhancement, though the SON behavior will be shown to be a result of IOD interference in a following section. Furthermore, this corresponds with work by Richard et al. (2002) that reported a seasonal shift between spring and summer rainfall in South Africa as being coupled to a main mode of precipitation variability, though not specifically attributed to ENSO-IOD interactions. Similarly, photosynthesis across West Africa switches from IOD suppression during MAM to enhancement during the rest of the year. Also noteworthy is the stronger photosynthesis response to La Niña than El Niño for the Sahelian region during JJA, consistent with both rainfall and $f_{\mathrm{PAR}}$ (Fig. 2). Equatorial and East African relationships to ENSO phases remain notably consistent year-round, namely the DRC, Tanzanian, and Ethiopian regions (Table 1, Fig. 2). 


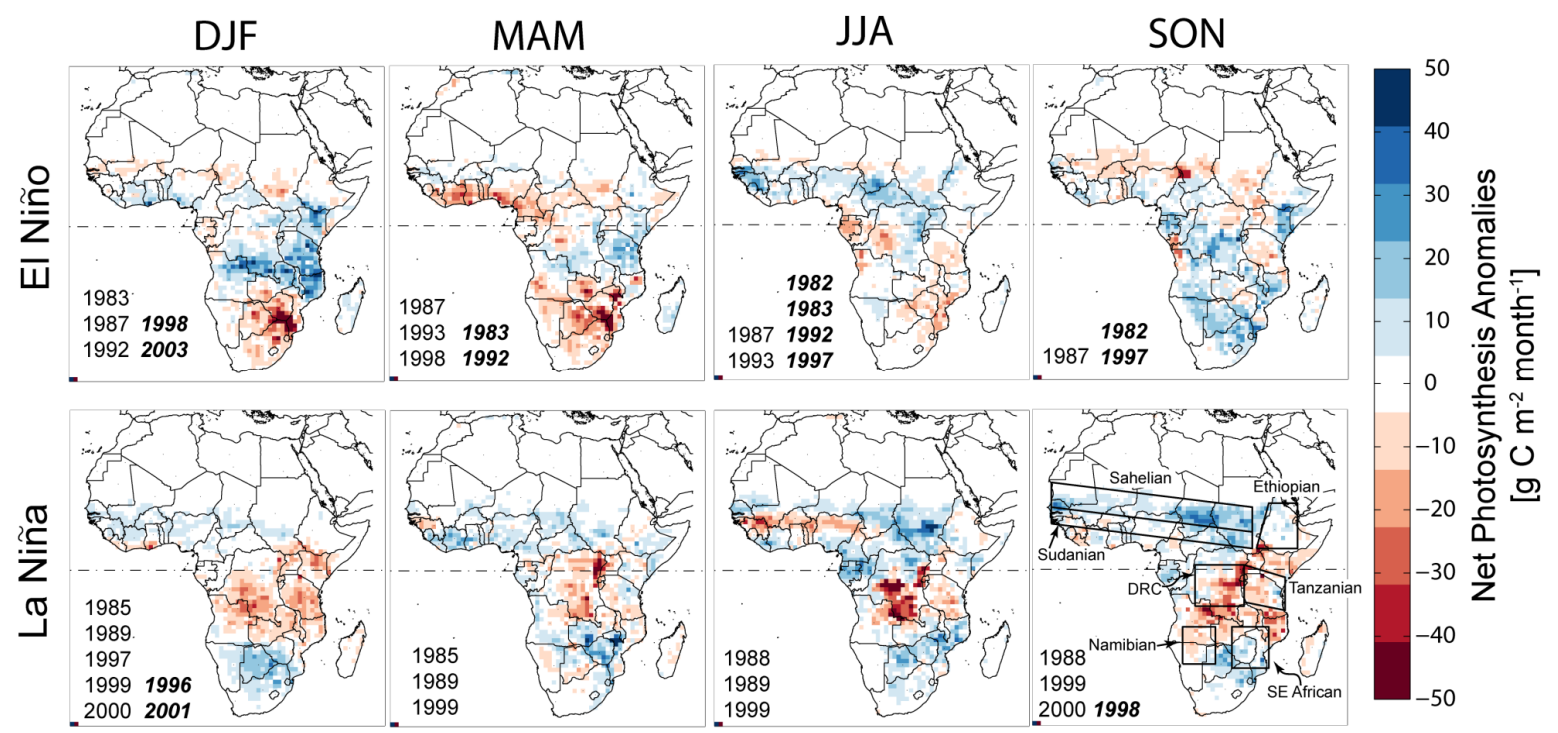

Fig. 1a. Spatial distribution across Africa of index-and phase-specific composite anomalies of net photosynthesis for each of the four climatic seasons (e.g. DJF = December-January-February) for (a) ENSO and (b) IOD relations, regardless of possible coincidences. Years reported for DJF refer to the JF calendar year and the previous year's D. Years inset within each panel list those contributing to each composite, where pure events are shown with normal text and coincident events are in bold and italicized. The lower right panel displays the geographic extents of regional composites highlighted in the paper.

Regarding drivers, photosynthesis anomalies are generally accompanied by a similarly signed response of rainfall (Table 1) underscoring the prevailing influence of water limitation in controlling temporal variability of net photosynthesis across much of the continent (Williams et al., 2008). More than $90 \%$ of the sizeable photosynthesis anomalies (absolute value greater than $5 \mathrm{gC} \mathrm{m}^{-2}$ month $^{-1}$ ) are accompanied by same signed responses of rainfall, and more than $70 \%$ are compatible with $f_{\mathrm{PAR}}$ anomalies. There are some notable exceptions indicating that (a) rainfall and $f_{\mathrm{PAR}}$ responses diverge, (b) rainfall surpluses make photosynthesis insensitive to rainfall anomalies, or (c) lack of vegetation cover restricts photosynthetic response. For example, rainfall increases in Tanzania during SON El Niños are matched with little change in photosynthesis (Table 1) owing to simultaneous $f_{\mathrm{PAR}}$ reduction during a time of year when vegetation cover is already relatively low. As another example, in Tanzania and the DRC, MAM photosynthesis increases with El Niño are coincident with little or opposite-signed anomalies of rainfall but slightly elevated $f_{\mathrm{PAR}}$. Such inconsistencies between $f_{\mathrm{PAR}}$ and rainfall anomalies may derive from disturbance or management driven changes in vegetation (and $f_{\mathrm{PAR}}$ ), hydrologic surpluses that buffer vegetation response to rainfall anomalies, or possibly errors in one or both datasets.

Rainfall and hence photosynthesis relations to ENSO (Fig. 1) are broadly consistent with the patterns documented by Nicholson and Kim (1997) and Nicholson (2001) analyzing rain gauge data. Photosynthesis anomalies are also consistent with patterns reported from analysis of vegetation index such as the 1997/1998 warm event NDVI anomalies documented by Anyamba et al. (2001). Still, we note that the absolute magnitudes of southern Africa's $f_{\mathrm{PAR}}$ and photosynthesis responses are stronger in the east, where Anyamba et al. (2001) reported strong relative increases in the western half of southern Africa. In contrast, photosynthesis patterns are inconsistent with ENSO-driven gross primary productivity patterns reported by Jones et al. (2001). Their findings resulted from simulation with the coupled Hadley Centre general circulation model (HadCM3LC) coupled to a dynamic vegetation model (TRIFFID). Disagreement with their results may be related to lack of correspondence between gauge-based rainfall and estimates generated by the GCM implementation, such that the Jones et al. (2001) results are likely to provide a poor representation of Africa's ENSO response. Our results are much closer to those reported by Hashimoto et al. (2004) who found continent-wide reductions in net primary productivity with El Niño and increases with La Niña events. Even so, we find a more extensive region of positive relationships to ENSO in Central and East Africa that is consistent with rainfall. The discrepancy could be linked to the fact that the Hashimoto et al. (2004) model does not consider rainfall and relies only on vapor pressure deficit and $f_{\mathrm{PAR}}$ to represent plant water status.

\subsubsection{IOD associations}

Turning to relations with the IOD, we find anomalies of a similar intensity to those excited by ENSO. Net photosynthesis is strongly coupled to IOD in regionally coherent spatial patterns across much of the continent (Fig. 1b). Positive 
Table 1. Climate-season averaged anomalies for specific regions across Africa associated with all ENSO and IOD events regardless of possible coincidence. Shown are photosynthesis $\left(P_{\text {net }}, \mathrm{g} \mathrm{C} \mathrm{m}^{-2} \mathrm{month}^{-1}\right)$, rainfall $\left(R, \mathrm{~mm} \mathrm{month}^{-1}\right)$, and vegetation fractional PAR absorption $(V$, absorbed fraction of total). Bold values indicate significant $(P$-value $<0.1)$ differences relative to non-index periods based on a Student's two-sample t-test.

\begin{tabular}{|c|c|c|c|c|c|c|c|c|c|c|c|c|}
\hline & \multicolumn{3}{|c|}{ DJF } & \multicolumn{3}{|c|}{ MAM } & \multicolumn{3}{|c|}{ JJA } & \multicolumn{3}{|c|}{ SON } \\
\hline & $P_{\text {net }}$ & $R$ & $V$ & $P_{\text {net }}$ & $R$ & $V$ & $P_{\text {net }}$ & $R$ & $V$ & $P_{\text {net }}$ & $R$ & V \\
\hline \multicolumn{13}{|l|}{ El Niño } \\
\hline Sahelian & -3 & 0 & 0 & 0 & 0 & 0 & 0 & -7 & 0 & -5 & -2 & 0 \\
\hline Sudanian & 1 & -1 & 0 & -3 & -4 & -1 & 11 & -4 & 2 & 1 & 1 & 1 \\
\hline Ethiopian & 3 & 4 & 2 & 1 & 13 & 0 & 3 & -6 & 1 & 1 & 14 & 0 \\
\hline DRC & 9 & 7 & 1 & 3 & -8 & 0 & 1 & 1 & 0 & 9 & 22 & 2 \\
\hline Tanzanian & 15 & 14 & 4 & 11 & -8 & 0 & -3 & -3 & -2 & -1 & 39 & -1 \\
\hline Namibian & -2 & -16 & -1 & -9 & 0 & -3 & 3 & 3 & -1 & 11 & 10 & 0 \\
\hline SE African & -15 & -47 & -4 & -19 & -12 & -3 & -7 & 5 & -3 & 8 & 7 & 2 \\
\hline \multicolumn{13}{|l|}{ La Niña } \\
\hline Sahelian & 3 & -1 & 0 & 4 & 1 & 1 & 8 & 22 & 1 & 11 & 0 & 2 \\
\hline Sudanian & 4 & 0 & 0 & 3 & 0 & 0 & -3 & 14 & 1 & 5 & -3 & 1 \\
\hline Ethiopian & -2 & -3 & 0 & 1 & 0 & 1 & 0 & 13 & 1 & 0 & 0 & 2 \\
\hline DRC & -11 & -7 & -2 & -10 & 1 & -1 & -15 & 6 & 2 & -12 & -7 & 0 \\
\hline Tanzanian & -11 & -12 & $-\mathbf{3}$ & -1 & 7 & 1 & -5 & 0 & 1 & -7 & -22 & 0 \\
\hline Namibian & 6 & 19 & 1 & 3 & -5 & -1 & 3 & 0 & 0 & -3 & -10 & -2 \\
\hline SE African & 4 & 44 & -1 & 12 & 13 & 2 & 9 & -1 & 2 & 3 & -1 & -1 \\
\hline \multicolumn{13}{|l|}{ IOD Pos } \\
\hline Sahelian & 0 & -1 & 0 & 1 & 1 & 0 & 0 & 4 & 0 & 0 & 3 & 0 \\
\hline Sudanian & 2 & 2 & 0 & 4 & 2 & 1 & -5 & 0 & -2 & 3 & 1 & 1 \\
\hline Ethiopian & 0 & 8 & 1 & -3 & -8 & 0 & -1 & 1 & -1 & 1 & 7 & 0 \\
\hline DRC & -2 & 5 & -1 & -2 & 1 & -1 & 0 & 0 & $-\mathbf{3}$ & 9 & 10 & -1 \\
\hline Tanzanian & 9 & 15 & 3 & -11 & -3 & -1 & -8 & 2 & -2 & -1 & 29 & 0 \\
\hline Namibian & -1 & -5 & -2 & 6 & -2 & 1 & 1 & 1 & -1 & 5 & 3 & 2 \\
\hline SE African & 11 & 10 & 0 & 4 & -2 & 0 & -5 & 1 & -1 & 0 & 1 & 3 \\
\hline \multicolumn{13}{|l|}{ IOD Neg } \\
\hline Sahelian & -14 & -3 & -1 & -5 & -2 & 0 & 0 & -3 & 0 & -1 & -3 & 0 \\
\hline Sudanian & -8 & 5 & 1 & -8 & -9 & 0 & 1 & 1 & 0 & 2 & 0 & 0 \\
\hline Ethiopian & 0 & 22 & 0 & -2 & 2 & 0 & 1 & 2 & 0 & 0 & 2 & -1 \\
\hline DRC & 9 & 58 & 0 & 2 & 7 & 0 & 3 & -4 & 2 & 0 & -1 & 0 \\
\hline Tanzanian & 16 & -18 & 6 & 1 & -5 & -1 & 10 & -1 & 2 & 7 & -5 & 1 \\
\hline Namibian & -29 & -6 & 0 & -12 & 3 & -3 & 0 & -1 & 1 & 0 & 1 & 0 \\
\hline SE African & -54 & -40 & -7 & -34 & -11 & -5 & 6 & 0 & 1 & -3 & -3 & -1 \\
\hline
\end{tabular}

photosynthesis association is found for nearly all of Africa south of the equator except Tanzania and part of Mozambique, with elevation (suppression) during the positive (negative) phase. This is broadly consistent with Reason and Rouault (2002) who report positive correlation between rain and IOD in southeastern Africa. However, we find that southern African association with IOD shifts seasonally and that negative phase responses are stronger (Figs. 1b, 2, Table 1). Responses across Sudanian and Sahelian zones are weak (Figs. 1b, 2, Table 1). Negative phase DJF and MAM responses offer modest exceptions but both are poor represen- tations of pure IOD responses being coincident with ENSO activity as described in a following section.

Negative IOD association is found for Tanzania, northern Democratic Republic of the Congo, and the Guinean zone spanning coastal West Africa up to 10 degrees north latitude. Though the Tanzanian positive phase IOD relationship appears to shift seasonally with enhancement during DJF and suppression during MAM and JJA (Table 1, Fig. 2), the DJF enhancement is annulled when pure IOD events are separated from those coincident with ENSO as shown in a following section. Furthermore, the well-reported SON elevation of 


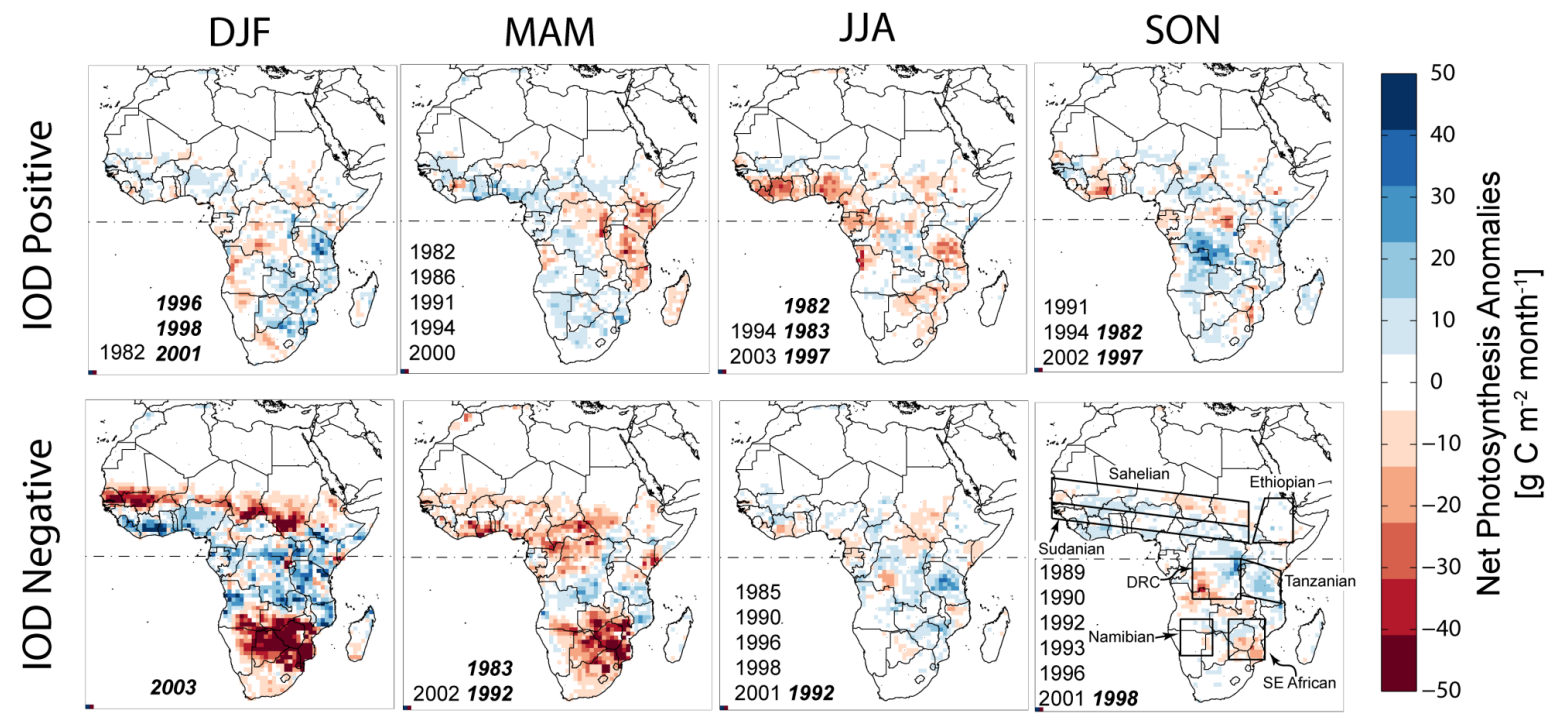

Fig. 1b. Same as Fig. 1a but for IOD relations.
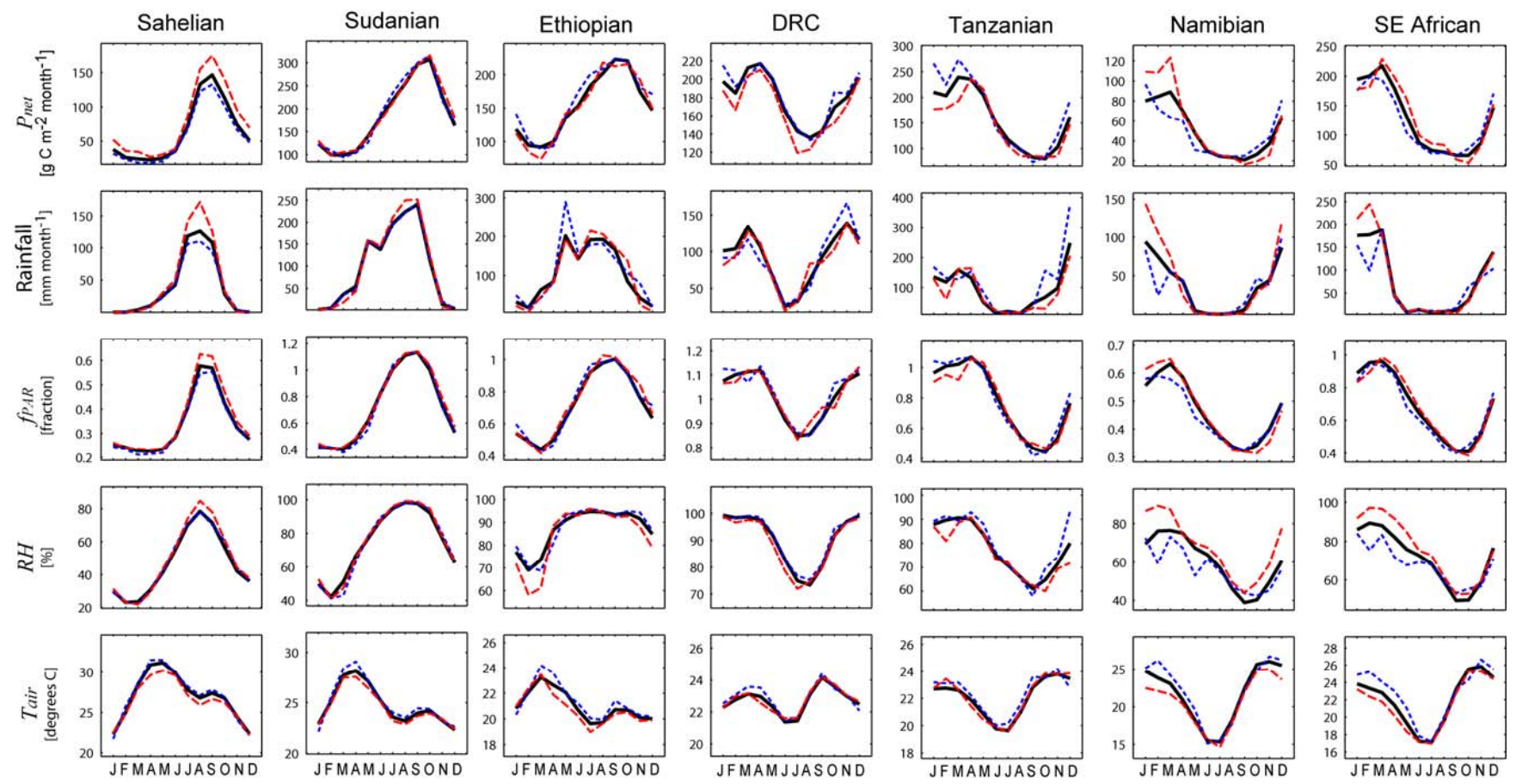

Fig. 2. Monthly average, composite regional series averaged for all years (solid black), for the lowest three ENSO excursions (blue dotted, El Niño phase), and highest three ENSO excursions (red longer dash, La Niña phase) shown for net photosynthesis $\left(P_{\text {net }}\right)$, rainfall, fractional absorbance of PAR $\left(f_{\mathrm{PAR}}\right)$, relative humidity $(\mathrm{RH})$, and air temperature $\left(T_{\text {air }}\right)$.

rainfall in East Africa during positive phase IOD events (Behera and Yamagata, 2003; Black et al., 2003) does not elicit a response in modeled photosynthesis (Fig. 1b, Table 1) because of coincidence with reduced vegetation cover $\left(f_{\mathrm{PAR}}\right)$ though this is only revealed when pure IOD events are separated from those coincident with ENSO activity as also examined in a following section. For coastal West Africa the response also switches from season to season with positive phase enhancement during MAM and suppression during JJA, and negative phase enhancement during DJF and suppression during MAM though again we note that DJF and MAM composites cannot be considered as representing responses to pure negative phase IOD events given coincident ENSO activity. 

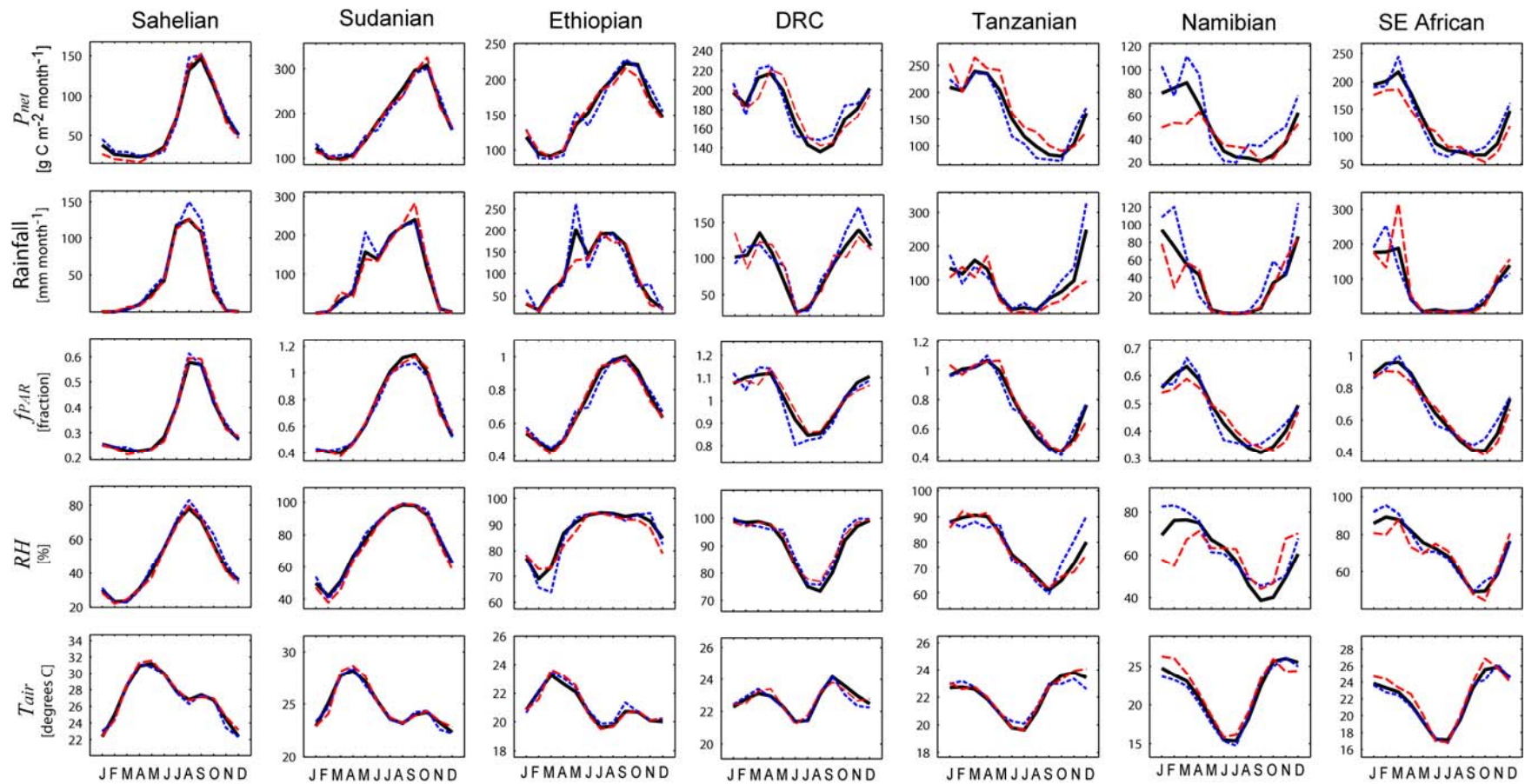

Fig. 3. Monthly average, composite regional series averaged for all years (solid black), for the lowest three IOD excursions (blue dotted), and highest three IOD excursions (red longer dash) shown for net photosynthesis $\left(P_{\text {net }}\right)$, rainfall, fractional absorbance of PAR $\left(f_{\mathrm{PAR}}\right)$, relative humidity $(\mathrm{RH})$, and air temperature $\left(T_{\text {air }}\right)$.

As with ENSO, IOD-excited anomalies of photosynthesis are largely driven by rainfall. More than $80 \%$ of the sizeable photosynthesis anomalies (absolute value greater than $5 \mathrm{gC} \mathrm{m}^{-2}$ month $^{-1}$ ) are accompanied by same signed responses of rainfall, however only $40 \%$ are compatible with $f_{\text {PAR }}$ anomalies (Table 1). Vegetation cover/vigor $\left(f_{\mathrm{PAR}}\right)$ explains most of the inconsistencies between photosynthesis and rainfall anomalies (e.g. Tanzania, negative phase IOD during DJF or SON, Table 1).

\subsection{Temporal structure of associations}

We now examine the structure of temporal association between photosynthesis and climate oscillations in regions of coherent responses using spatial composites. Each composite region, as pictured in Fig. 1, is centered on a particular hotspot but is expanded to have a sample more representative of the regional pattern. The composite areas are arbitrary in geographic extent and are intended to highlight the nature of functionally coherent regional responses to each index rather than provide an exhaustive description of all interesting patterns across the continent. Still, these areas were selected as examples of regions in which photosynthesis can be expected to respond strongly to the global climate phenomena of ENSO and IOD. Composite time series were produced from 13-month running mean deseasonalized, linearly-detrended and z-score standardized grid-cell responses to each index averaged over cells within the region.
Correlations between climate indices and net photosynthesis anomalies are clearly evident with little to no lag for particular regions (Fig. 4). Time series plots indicate joint influences of ENSO and IOD, noticeable during periods when a large departure in one index coincides with little departure in the other. For example, during the 1991 to 1995 period when ENSO excursions are small but the IOD had an intense cycle, DRC and Namibian composites show sensitivity to IOD. Similarly, during the 1987 to 1990 period when IOD excursions were small but the ENSO had an intense cycle all of the regional composites show some corresponding anomalies except perhaps the Sudanian region (Fig. 4).

The ENSO and IOD indices are most notably in alignment from 1997 to 1999 with intense cycles in both. During this period, the southern Africa regions (Namibian, SE African) show unusual positive association with ENSO, likely owing to the typically positive response to IOD characteristic of the region and indicating destructive interference with a dominant response to IOD forcing. This is consistent with a recent analysis of rainfall in Zimbabwe by Manatsa et al. (2008) that similarly suggests IOD dominance over ENSO when the two are in competition.

Destructive interference is also evident for the same period (1997-1999) but for the Sahelian region, which shows an unusual absence of negative association with ENSO likely owing to the region's typically positive association with IOD. A correspondingly dampened response to IOD forcing is found in the Sahelian region during this period of coincident 

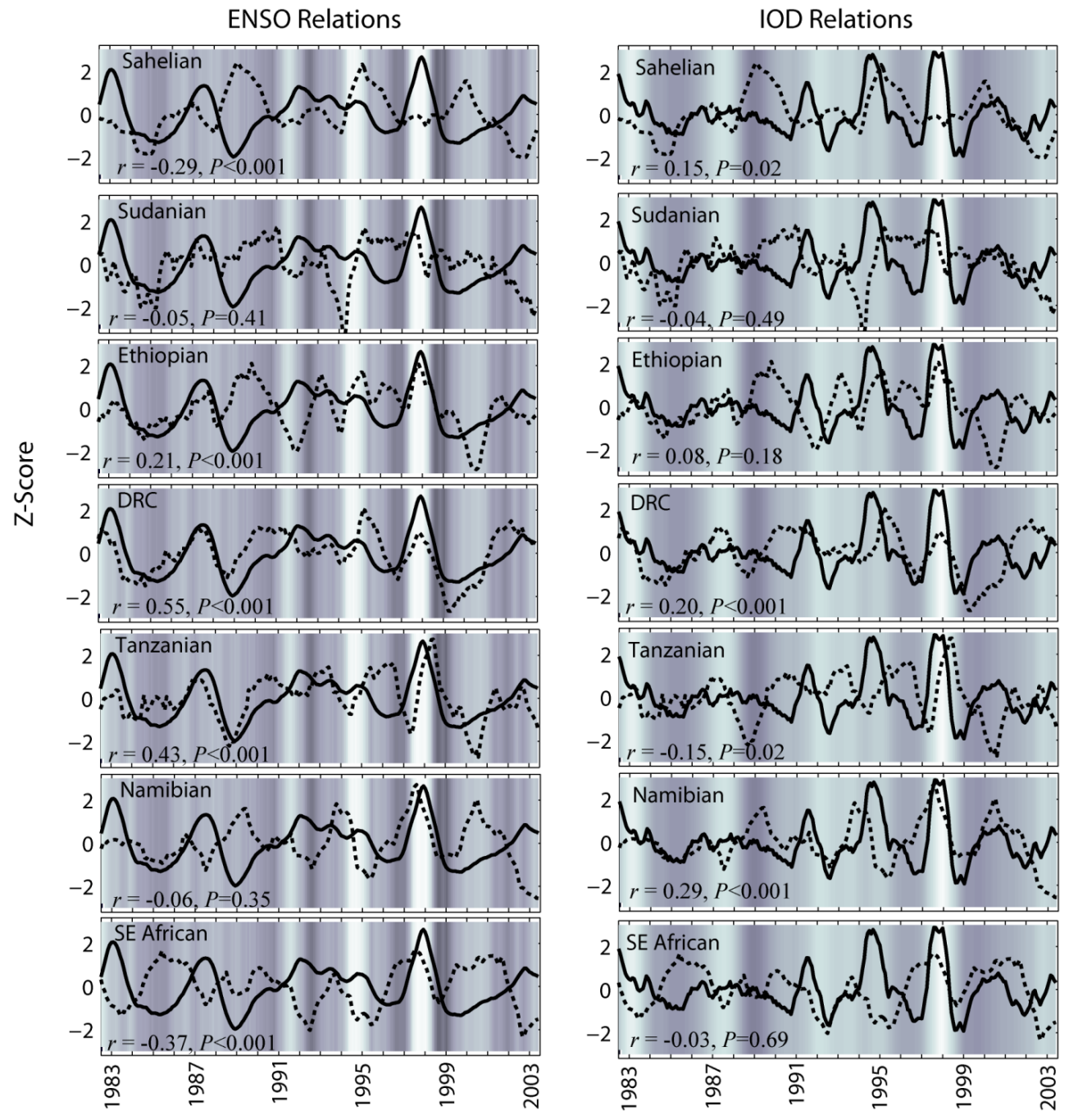

Fig. 4. Time series of net photosynthesis (dotted line) for select regions (see Fig. 1) with the climate indices (solid lines) ENSO (left column) and IOD (right column) for the period 1982 through 2003, where series are smoothed with a 13-month, symmetrical running mean and linearly detrended, and presented as standardized z-scores. Shading underlying the time series indicates the intensity of the other climate index, where white (dark grey) is the maximum positive (minimum negative) anomaly. Correlation coefficients $(r)$ and significance $(P)$ are inset for each panel.

positive phases between the ENSO and IOD. The Ethiopian region indicates unusual positive association with IOD during the 1997 to 1999 window suggesting ENSO dominance over IOD forcing consistent with a statistically significant relation to ENSO but not IOD (Table 1).

\subsection{Independent versus interactive effects}

Suggestions of interactive effects are corroborated by twoway, type 1 analysis of variance (ANOVA) testing for effects of independent and interactive effects of ENSO and IOD on monthly anomalies of photosynthesis, rainfall, and $f_{\mathrm{PAR}}(\mathrm{Ta}-$ ble 2). ENSO-IOD interactions have a statistically significant $(P<0.05)$ effect on photosynthesis for nearly all of the selected regions. Corresponding ENSO-IOD interactive effects on rainfall or $f_{\mathrm{PAR}}$ are also evident but vary by region.
To assess magnitudes of independent and interactive effects we further stratify seasonal responses into those with and without simultaneous events, labeled "coincident" and "pure", respectively. Years with pure and coincident events are reported in panels of Fig. 1. In the presence of IOD activity, photosynthesis in the southern Africa region exhibits a large reversal of response to SON El Niño and La Niña events, where the typical negative association reverses to a large positive association (Table 3). This derives mainly from reversal of typical negative $f_{\mathrm{PAR}}$ association during pure events to sizeable positive association during coincident events (Table 3).

A similar IOD-induced shift in ENSO association is found for Tanzania, where the typical photosynthesis response to ENSO is suppressed or changes sign when coincident with 
Table 2. $P$-values from two-way, Type-1 ANOVAs testing for effects of ENSO, IOD, and their interaction on monthly averages of net photosynthesis $\left(P_{\text {net }}\right)$, rainfall $(R), f_{\mathrm{PAR}}(V)$ for select geographic regions. ENSO and IOD series were treated as grouping variables based on phase (upper and lower quintiles, or neutral). Significance is indicated by bold or italicized text at $P<0.05$ or $P<0.10$. This analysis uses all ENSO and IOD events regardless of their possible coincidence.

\begin{tabular}{llccccccc}
\hline & & Sahelian & Sudanian & Ethiopian & DRC & Tanzanian & Namibian & SE African \\
\hline \multirow{2}{*}{$P_{\text {net }}$} & ENSO & $\mathbf{0 . 0 0}$ & $\mathbf{0 . 0 3}$ & 0.09 & $\mathbf{0 . 0 0}$ & $\mathbf{0 . 0 1}$ & 0.07 & $\mathbf{0 . 0 0}$ \\
& IOD & $\mathbf{0 . 0 3}$ & - & - & - & - & $\mathbf{0 . 0 1}$ & $\mathbf{0 . 0 0}$ \\
& ENSOxIOD & $\mathbf{0 . 0 1}$ & $\mathbf{0 . 0 1}$ & 0.05 & $\mathbf{0 . 0 3}$ & $\mathbf{0 . 0 0}$ & $\mathbf{0 . 0 0}$ & $\mathbf{0 . 0 0}$ \\
\hline \multirow{2}{*}{$R$} & ENSO & - & - & - & - & - & 0.10 & $\mathbf{0 . 0 0}$ \\
& IOD & - & - & 0.06 & - & $\mathbf{0 . 0 0}$ & - & - \\
& ENSOxIOD & $\mathbf{0 . 0 0}$ & $\mathbf{0 . 0 1}$ & - & $\mathbf{0 . 0 0}$ & $\mathbf{0 . 0 0}$ & - & - \\
\hline \multirow{2}{*}{$V$} & ENSO & $\mathbf{0 . 0 0}$ & - & 0.09 & - & - & $\mathbf{0 . 0 2}$ & $\mathbf{0 . 0 0}$ \\
& IOD & 0.06 & - & 0.05 & - & - & - & $\mathbf{0 . 0 1}$ \\
& ENSOxIOD & $\mathbf{0 . 0 0}$ & - & 0.08 & - & - & $\mathbf{0 . 0 0}$ & $\mathbf{0 . 0 0}$ \\
\hline
\end{tabular}

Table 3. Mean El Niño and La Niña anomalies in net photosynthesis $\left(P_{\text {net }}\right)$, rainfall $(R)$, and $f_{\mathrm{PAR}}(V)$ for pure $(P)$ and coincident $(C)$ events during two climatic seasons and in two hotspot regions. Bold and italicized texts indicate significant $(P<0.05, P<0.10)$ differences between pure and coincident populations based on t-tests. Years included in each composite were as follows: (1) SON-Pure: EN 1987; LN 1988, 1999, 2000; (2) SON-Composite: EN 1982, 1997; LN 1998; (3) DJF-Pure: EN 1983, 1987, 1992; LN 1985, 1989, 1997, 1999, 2000; (4) DJF-Coincident: EN 1998, 2003; LN 1996, 2001.

\begin{tabular}{|c|c|c|c|c|c|c|c|c|c|c|c|c|}
\hline & \multicolumn{6}{|c|}{ SON } & \multicolumn{6}{|c|}{ DJF } \\
\hline & \multicolumn{2}{|c|}{$P_{\text {net }}$} & \multicolumn{2}{|c|}{$R$} & \multicolumn{2}{|c|}{ V } & \multicolumn{2}{|c|}{$P_{\text {net }}$} & \multicolumn{2}{|c|}{$R$} & \multicolumn{2}{|c|}{$V$} \\
\hline & $P$ & $C$ & $P$ & C & $P$ & $C$ & $P$ & $C$ & $P$ & C & $P$ & $C$ \\
\hline \multicolumn{13}{|l|}{ El Niño } \\
\hline Tanzanian & 4 & -4 & -15 & 0 & -1 & 11 & 21 & 8 & 23 & 2 & 8 & \\
\hline SE African & -10 & 17 & -4 & 12 & -3 & 4 & -15 & -17 & -56 & -35 & -4 & -3 \\
\hline \multicolumn{13}{|l|}{ La Niña } \\
\hline Tanzanian & -15 & 16 & -17 & -36 & -1 & 2 & -17 & 4 & -27 & 25 & -5 & \\
\hline SE African & 14 & -29 & -1 & -2 & 0 & -2 & 5 & 1 & 48 & 34 & 0 & -3 \\
\hline
\end{tabular}

IOD activity (Table 3). This is most notable for SON responses to La Niña and is largely associated with $f_{\mathrm{PAR}}$ (Table 3). Such reversals are less pronounced or absent during the DJF season in both regions. This is likely related to the fact that IOD activity tends to peak in SON and be less persistent than the typical ENSO activity that has broader peaks often centered on DJF. Correspondingly, there are few pure DJF, IOD events. In part because of the limited sample sizes, but also to explore independent and combined influences, Fig. 5 presents results of a partial correlation analysis. As much as $30 \%$ to $40 \%$ of the interannual variability in photosynthesis, rainfall, or $f_{\mathrm{PAR}}$ can be explained by the ENSO and IOD indices combined in select "hotspot" regions. Futhermore, there is some suggestion that ENSO is responsible for more of the variability in the southern African regions, while IOD may explain more of the variability in the Tanzanian region.
Taken together, coincidence of IOD and ENSO activity appears to result in destructive interference that can suppress or overturn a region's response typical of pure events. This strongly suggests a need to consider the simultaneous states of ENSO and IOD when examining teleconnections across Africa though the only small sample of pure and coincident events precludes definitive conclusions regarding the nature of their independent and interactive effects. Still, this study documents a first indication of a potentially important phenomenon that needs to be re-evaluated with more extensive records that will become available over time.

\section{Conclusions}

Teleconnections between African photosynthesis and the oceanic temperature and pressure patterns of the El Niño Southern Oscillation (ENSO), the Indian Ocean Dipole (IOD) are strongly evident in our analyses. In addition to 

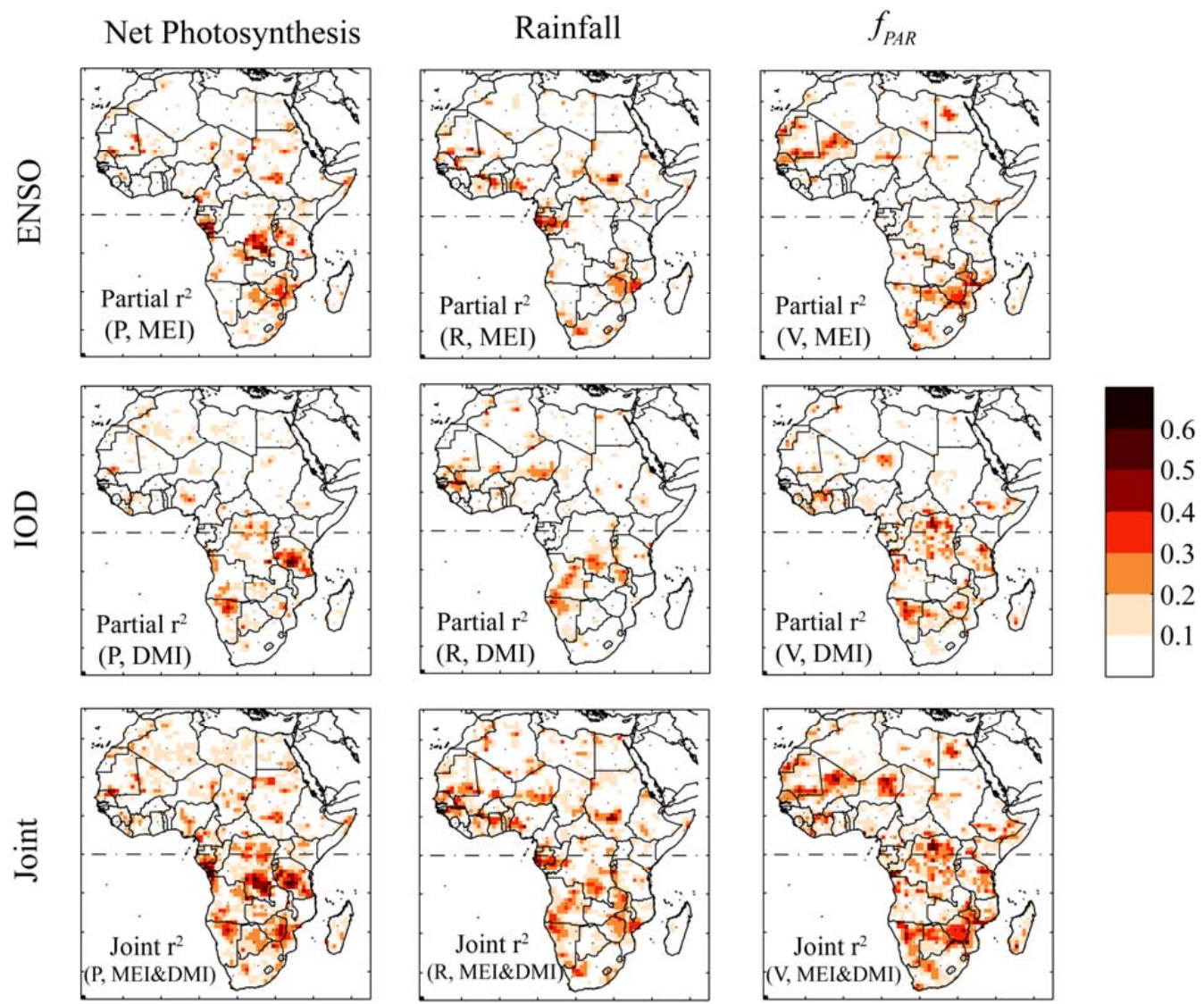

Fig. 5. Partial and joint correlations squared $\left(r^{2}\right)$ from partial correlation analysis of net photosynthesis, rainfall, or $f_{\mathrm{PAR}}$ with the ENSO and IOD indices (MEI and DMI, respectively).

the relatively well-known ENSO forcing, the IOD also induces large seasonal anomalies of precipitation, vegetation, humidity and thus photosynthesis across much of Africa.

Photosynthesis is especially sensitive to these ocean climate oscillations in particular regions. With ENSO the regions of greatest sensitivity include most of the Great Rift Valley, traversing equatorial eastern Africa to eastern southern Africa, western equatorial Africa, and some of the Sahelian zone. Most resonant with IOD fluctuations are the Congo Basin, Tanzania, parts of the Kalahari and Miombo regions, as well as parts of coastal West Africa.

Regions sensitive to ENSO and IOD overlap in their geographic distributions, and in some cases teleconnections interfere with each other. Destructive interferences prevail causing cancellation or even reversal of typical independent effects most notably in equatorial East African and southern African regions. Continued efforts are needed to disentangle the independent and joint influences of these climate anomalies on water and carbon dynamics across Africa. This is important not only to clarify the mechanisms driving variability in Africa's carbon cycle but also to inform early warning and decision support efforts aimed at mitigating climate-related disasters.

\section{Appendix A}

\section{Model description and implementation}

The model, Simple Biosphere (SiB) (Sellers et al., 1996a, b, c) estimates gross photosynthesis with a modified version of the Farquhar et al. (1980) model (Collatz et al., 1991) scaled by the canopy integration scheme of Sellers et al. (1996c) and coupled to the Ball-Berry stomatal conductance model (Ball et al., 1988; Collatz et al., 1991, 1992). Net photosynthesis accounts also for leaf respiration, which is on the order of $10 \%$ of gross photosynthesis. SiB scales these "topleaf" photosynthetic rates to the canopy with the integration scheme of Sellers et al. (1992) that defines a canopy-scale, photosynthetically active radiation use parameter (П) estimated from the fractional absorption of photosynthetically active radiation $\left(f_{\mathrm{PAR}}\right)$ derived from remotely sensed Normalized Difference Vegetation Index (NDVI), and vegetation type.

The model's surface energy balance includes separate vegetation and ground temperatures that change according to net radiative input minus sensible and latent heat fluxes. The model's surface water balance is composed of canopy 
interception, ponding, soil, and snow balance equations that include inputs from precipitation or direct condensation, losses to evaporation, transpiration or sublimation, as well as inter-layer exchanges, where appropriate. Runoff occurs as deep gravity drainage and lateral flows during periods of infiltration excess.

The newest version (SiB3) includes a prognostic canopy air space for temperature, moisture, and $\mathrm{CO}_{2}$ (Vidale and Stöckli, 2005), and a 10-layer soil with explicit treatment of temperature and moisture based on the common land model (Dai et al., 2003). Also added is a mixed plant canopy physiology used here to simulate canopy-atmosphere exchanges for C3 and C4 plants separately (Hanan et al., 2005), though they have the same soil water, radiation, and canopy air space environment.

Model inputs for this implementation included soil texture (Tempel et al., 1996), vegetation type (DeFries, 1998; Hansen et al., 2000), and the fraction of $\mathrm{C} 4$ vegetation (Still et al., 2003). To obtain an observationally-consistent vegetation parameterization, as well as phenomenologically correct soil water limitation of photosynthesis in the Sahelian zone (open savannas to the south of the Sahara desert) it was necessary to extend the coverage of short, wooded C4 grassland further north to replace the $\mathrm{C} 3$ bare soil parameterization that were prescribed in the original vegetation datasets. This change is consistent with field observations of vegetation cover in the region.

Surface weather was prescribed based on National Centers for Environmental Prediction Reanalysis 2. However, the 6-hourly precipitation was adjusted to obtain total monthly rainfall that matches the remote sensing plus gauge data merged Tropical Rainfall Measuring Mission 3B43 rainfall product for 1998 through 2003. For earlier years (19821997) we used Climate Research Unit (CRU) (Mitchell and Jones, 2005; New et al., 2000) monthly totals, adjusted to be consistent with the TRMM 3B43 monthly average spatial pattern from their period of overlap (1998-2001).

To prescribe vegetation dynamics we used the twice monthly, $\sim 8 \mathrm{~km}$ NDVI for years 1982-2003 made available by the Global Inventory Modeling and Mapping Studies (GIMMS) team (Pinzon, 2002, 2005; Tucker et al., 2006) derived from Advanced Very High Resolution Radiometer (AVHRR). The Simple Biosphere model also contains algorithms, described in Sellers et al. (1994) and Los et al. (1998, 2000), for estimating a suite of light interception, surface roughness, resistance, and physiological parameters based on remotely-sensed vegetation index. While the NDVI dataset contains corrections for satellite orbital drift, differing instrument calibrations, sensor degradation, and volcanic aerosols, we found large negative spikes of NDVI in many areas prone to cloud cover, and therefore replaced the lower twenty percent of NDVI of each biweek across years and at each $\sim 8 \mathrm{~km}$ grid-cell with the mean of the upper eighty percent. Furthermore, we found unusual seasonal dynamics in NDVI even after this lower-fifth replacement, and dis- covered that this seasonal pattern is strongly anticorrelated with pyrogenic or mineral aerosol loads measured by the MODerate Resolution Imaging Spectroradiometer (MODIS) Terra Level-3 monthly atmospheric aerosol optical thickness (MOD08_M3). Therefore we performed an ad hoc adjustment to the AVHRR NDVI data so that their biweekly average seasonality matches the average seasonality seen with a filled, $5 \mathrm{~km}$ MODIS NDVI product covering the five-year period of 2000 to 2004. This approach retains seasonal and interannual variability in the AVHRR NDVI and hence vegetation structure and function, but removes much of the erroneous seasonality associated with aerosol and water vapor contamination.

Since each of these datasets (weather, soil type, vegetation type, NDVI, etc.) contains a unique resolution or grid, we selected a land point mask based on the 0.0727 degree by 0.0727 degree NDVI dataset and regridded the other datasets to match using a bilinear interpolation (except for vegetation type which was regridded based on assignment of a nearest neighbor without interpolation). These 0.0727 degree datasets were then upscaled to the 1 degree grid with bilinear interpolation except for vegetation type which was assigned the most frequent occurrence.

Acknowledgements. The authors thank Ian Baker for his guidance with model simulations, A. Scott Denning for providing computational resources, and Alfredo Huete for providing gap-filled, gridded $5 \mathrm{~km}$ MODIS NDVI. Funding for this study was provided by the United States National Aeronautics and Space Administration (NASA) Terrestrial Ecology Program (Diane Wickland), and the National Oceanic and Atmospheric Administration (NOAA) Global Carbon Cycle Program (Kathy Tedesco).

Edited by: G. Wohlfahrt

\section{References}

Alexander, M. A., Blade, I., Newman, M., Lanzante, J. R., Lau, N.-C., and Scott, J. D.: The atmospheric bridge: the influence of ENSO teleconnections on air-sea interaction over the global oceans, J. Climate, 15(16), 2205-2231, 2002.

Allan, R. J., Chambers, D., Drosdowsky, W., Hendon, H., Laftif, M., Nicholls, N., Smith, I., Stone, R., and Tourre, Y.: Is there an Indian Ocean dipole, and is it independent of the El NinoSouthern Oscillations?, in: CLIVAR Exchanges, edited, 18-22, 2001.

Annamalai, H., Murtugudde, R., Potemra, J., Xie, S. P., Liu, P., and Wang, B.: Coupled dynamics over the Indian Ocean: Spring initiation of the zonal mode, Deep-Sea Res. Pt. II, 50, 23052330, 2003.

Annamalai, H., Xie, S.-P., McCreary, J. P., and Murtugudde, R.: Impact of Indian Ocean sea surface temperature on developing El Niño, J. Climate, 18, 302-319, 2005.

Anyamba, A. and Eastman, J. R.: Interannual variability of NDVI over Africa and its relation to El Nino Southern Oscillation, Int. J. Remote Sens., 17(13), 2533-2548, 1996. 
Anyamba, A. and Tucker, C. J.: Analysis of Sahelian vegetation dynamics using NOAA-AVHRR NDVI data from 1981-2003, J. Arid Environ., 63(3), 596-614, 2005.

Anyamba, A., Tucker, C. J., and Eastman, J. R.: NDVI anomaly patterns over Africa during the 1997/98 ENSO warm event, Int. J. Remote Sens., 22(10), 1847-1859, 2001.

Bacastow, R. B.: Modulation of Atmospheric Carbon-Dioxide by Southern Oscillation, Nature, 261, 116-118, 1976.

Balas, N., Nicholson, S. E., and Klotter, D.: The relationship of rainfall variability in West Central Africa to sea-surface temperature fluctuations, Int. J. Climatol., 27, 1335-1349, 2007.

Ball, M. C., Cowan, I. R., and Farquhar, G. D.: Maintenance of leaf temperature and the optimization of carbon gain in relation to water-loss in a tropical mangrove forest, Aust. J. Plant Physiol., 15(1-2), 263-276, 1988.

Behera, S. K. and Yamagata, T.: Influence of the Indian Ocean Dipole on the southern oscillation, J. Meteorol. Soc. Jpn., 8(1), 169-177, 2003.

Behera, S. K., Rao, S. A., Saji, H. N., and Yamagata, T.: Comments on "A cautionary note on the interpretation of EOFs", J. Climate, 16(7), 1087-1093, 2003.

Birkett, C., Murtugudde, R. G., and Allan, T.: Indian Ocean Climate event brings floods to East Africa's lakes and the Sudd Marsh, Geophys. Res. Lett., 26(8), 1031-1034, 1999.

Black, E.: The relationship between Indian Ocean sea-surface temperature and east African rainfall, Philos. T. Roy. Soc. A, 363, 43-47, 2005.

Black, E., Slingo, J. M., and Sperber, K. R.: An observational study of the relationship between excessively strong short rains in coastal East Africa and Indian Ocean SST, Mon. Weather Rev., 131(1), 74-94, 2003.

Boyer, D., Cole, J. and Bartholome, C.: Southwestern Africa: Northern Bengula Current region, Mar. Pollut. Bull., 41, 123$140,2000$.

Bryant, R. G., Bigg, G. R., Mahowald, N. M., Eckardt, F. D., and Ross, S. G.: Dust emission response to climate in southern Africa, J. Geophys. Res.-Atmos., 112, D09207, doi:10.1029/2005JD007025, 2007.

Chiang, J. C. H. and Sobel, A. H.: Tropical tropospheric temperature variations caused by ENSO and their influence on remote tropical climate, J. Climate, 15, 2616-2631, 2002.

Ciais, P., Piao, S.-L., Cadule, P., Friedlingstein, P., and Chédin, A.: Variability and recent trends in the African terrestrial carbon balance, Biogeosciences, 6, 1935-1948, doi:10.5194/bg-6-19352009, 2009.

Collatz, G. J., Ball, J. T., Grivet, C., and Berry, J. A.: Physiological and environmental-regulation of stomatal conductance, photosynthesis and transpiration - A model that includes a laminar boundary-layer, Agr. Forest Meteorol., 54(2-4), 107-136, 1991.

Collatz, G. J., Ribas-Carbo, M., and Berry, J. A.: Coupled Photosynthesis-Stomatal Conductance Model for Leaves of C4 Plants, Aust. J. Plant Physiol., 19(5), 519-538, 1992.

Dai, Y. J., Zeng, X. B., Dickinson, R. E., Baker, I., Bonan, G. B., Bosilovich, M. G., Denning, A. S., Dirmeyer, P. A., Houser, P. R., Niu, G. Y., Oleson, K. W., Schlosser, C. A., and Yang, Z. L.: The Common Land Model, B. Am. Meteorol. Soc., 84(8), 1013-1023, 2003.

DeFries, R., Hansen, M., Townshend, J. R. G., and Sohlberg, R.: Global land cover classifications at $8 \mathrm{~km}$ spatial resolution: The use of training data derived from Landsat imagery in decision tree classifiers, Int. J. Remote Sens., 19(16), 3141-3168, 1998.

Dommenget, D. and Latif, M.: A cautionary note on the interpretation of EOFs, J. Climate, 15(2), 216-225, 2002.

Dube, L. T. and Jury, M. R.: Structure and precursors of the 1992/93 drought in KwaZulu-Natal, South Africa from NCEP reanalysis data, Water Sa, 29(2), 201-207, 2003.

Farquhar, G. D., Caemmerer, S. V., and Berry, J. A.: A Biochemical-Model of Photosynthetic $\mathrm{CO}_{2}$ Assimilation in Leaves of C-3 Species, Planta, 149(1), 78-90, 1980.

Fischer, A. S., Terray, P., Guilyardi, E., Gualdi, S., and Delecluse, P.: Two independent triggers for the Indian ocean dipole/zonal mode in a coupled GCM, J. Climate, 18(17), 3428-3449, 2005.

Giannini, A., Saravanan, R., and Chang, P.: Oceanic forcing of Sahel rainfall on interannual to interdecadal time scales, Science, 302, 1027-1030, 2003.

Hachigonta, S. and Reason, C. J. C.: Interannual variability in dry and wet spell characteristics over Zambia, Clim. Res., 32(1), 4962, 2006.

Hanan, N. P., Berry, J. A., Verma, S. B., Walter-Shea, E. A., Suyker, A. E., Burba, G. G., and Denning, A. S.: Testing a model of $\mathrm{CO}_{2}$, water and energy exchange in Great Plains tallgrass prairie and wheat ecosystems, Agr. Forest Meteorol., 131(3-4), 162-179, 2005.

Hansen, M. C., Defries, R. S., Townshend, J. R. G., and Sohlberg, R.: Global land cover classification at $1 \mathrm{~km}$ spatial resolution using a classification tree approach, Int. J. Remote Sens., 21(6-7), 1331-1364, 2000.

Hashimoto, H., Nemani, R. R., White, M. A., Jolly, W. M., Piper, S. C., Keeling, C. D., Myneni, R. B., and Running, S. W.: El Niño-Southern Oscillation-induced variability in terrestrial carbon cycling, J. Geophys. Res.-Atmos., 109, D23110, doi:10.1029/2004JD004959, 2004.

Hirst, A. C. and Hastenrath, S.: Atmosphere-ocean mechanisms of climate anomalies in the Angola-Tropical Atlantic Sector, J. Phys. Oceanogr., 13, 1146-1158, 1983.

Hong, C.-C., Li, T., Ho, L., and Kug, J.-S.: Asymmetry in the Indian Ocean Dipole, Part I: Observational Analysis, J. Climate, 21, 4834-4848, doi:10.1175/2008JCLI2222.1, 2008a.

Hong, C.-C., Li, T., and Luo, J.-J.: Asymmetry of the Indian Ocean Dipole, Part II: Model Diagnosis, J. Climate, 21, 4849-4858, doi:10.1175/2008JCLI2222.1, 2008b.

Houghton, R. A.: Interannual variability in the global carbon cycle, J. Geophys. Res.-Atmos., 105(D15), 20121-20130, 2000.

Ingram, J. C. and Dawson, T. P.: Climate change impacts and vegetation response on the island of Madagascar, Philos. T. Roy. Soc. A, 363, 55-59, 2005.

Jones, C. D., Collins, M., Cox, P. M., and Spall, S. A.: The carbon cycle response to ENSO: A coupled climate-carbon cycle model study, J. Climate, 14(21), 4113-4129, 2001.

Jury, M. R.: The coherent variability of African river flows: Composite climate structure and the Atlantic circulation, Water Sa, 29(1), 1-10, 2003.

Kaplan, A., Cane, M. A., Kushnir, Y., Clement, A. C., Blumenthal, M. B., and Rajagopalan, B.: Analyses of global sea surface temperature 1856-1991, J. Geophys. Res.-Oceans, 103(C9), 18567$18589,1998$.

Kayanne, H., Iijima, H., Nakamura, N., McClanahan, T. R., Behera, S., and Yamagata, T.: Indian Ocean Dipole index recorded 
in Kenyan coral annual density bands, Geophys. Res. Lett., 33, L19709, doi:10.1029/2006GL027168, 2006.

Latif, M. and Groetzner, A.: The equatorial Atlantic oscillation and its response to ENSO, Clim. Dynam., 16, 213-218, 2000.

Los, S. O.: Linkages between Global Vegetation and Climate: An Analysis Based on NOAA-Advanced Very High Resolution Radiometer Data, Ph.D. Dissertation, Vrije Universiteit, Amsterdam, 1998.

Los, S. O., Collatz, G. J., Sellers, P. J., Malmstrom, C. M., Pollack, N. H., DeFries, R. S., Bounoua, L., Parris, M. T., Tucker, C. J., and Dazlich, D. A.: A global 9-yr biophysical land surface dataset from NOAA AVHRR data, J. Hydrometeorol., 1(2), 183199, 2000.

Manatsa, D., Chingombe, W., and Matarira, C. H.: The impact of the positive Indian Ocean dipole on Zimbabwe droughts, Int. J. Climatol., 28(15), 2011-2029, 2008.

Mapande, A. T. and Reason, C. J. C.: Links between rainfall variability on intraseasonal and interannual scales over western Tanzania and regional circulation and SST patterns, Meteorol. Atmos. Phys., 89(1-4), 215-234, 2005.

Marchant, R., Mumbi, C., Behera, S., and Yamagata, T.: The Indian Ocean dipole - the unsung driver of climatic variability in East Africa, Afr. J. Ecol., 45(1), 4-16, 2007.

Mitchell, T. D. and Jones, P. D.: An improved method of constructing a database of monthly climate observations and associated high-resolution grids, Int. J. Climatol., 25(6), 693-712, 2005.

Murtugudde, R. and Busalacchi, A. J.: Interannual variability of the dynamics and thermodynamics of the tropical Indian Ocean, J. Climate, 12(8), 2300-2326, 1999.

Nemani, R. R., Keeling, C. D., Hashimoto, H., Jolly, W. M., Piper, S. C., Tucker, C. J., Myneni, R. B., and Running, S. W.: Climatedriven increases in global terrestrial net primary production from 1982 to 1999, Science, 300, 1560-1563, 2003.

New, M., Hulme, M., and Jones, P.: Representing twentieth-century space-time climate variability. Part II: Development of 1901-96 monthly grids of terrestrial surface climate, J. Climate, 13(13), 2217-2238, 2000.

Nicholson, S. E.: The nature of rainfall variability over Africa on time scales of decades to millenia, Global Planet. Change, 26, 137-158, 2000.

Nicholson, S. E.: Climatic and environmental change in Africa during the last two centuries, Clim. Res., 17, 123-144, 2001.

Nicholson, S. E. and Kim, J.: The relationship of the El Niño Southern Oscillation to African rainfall, Int. J. Climatol., 17, 117-135, 1997.

Patra, P. K., Ishizawa, M., Maksyutov, S., Nakazawa, T., and Inoue, G.: Role of biomass burning and climate anomalies for land-atmosphere carbon fluxes based on inverse modeling of atmospheric $\mathrm{CO}_{2}$, Global Biogeochem. Cy., 19, GB3005, doi:10.1029/2004GB002258, 2005.

Paz, S., Tourre, Y. M., and Planton, S.: North Africa-West Asia (NAWA) sea-level pressure patterns and their linkages with the Eastern Mediterranean (EM) climate, Geophys. Res. Lett., 30, 1999, doi:10.1029/2003GL017862, 2003.

Philippon, N., Jarlan, L., Martiny, N., Camberlin, P., and Mougin, E.: Characterization of the interannual and intraseasonal variability of West African vegetation between 1982 and 2002 by means of NOAA AVHRR NDVI data, J. Climate, 20(7), 1202-1218, 2007.
Pinzon, J.: Using HHT to successfully uncouple seasonal and interannual components in remotely sensed data, paper presented at SCI 2002, Conference Proceedings 14-18 July, Orlando, Florida, 2002.

Pinzon, J., Brown, M. E., and Tucker, C. J.: Satellite time series correction of orbital drift artifacts using empirical mode decomposition, Chapt. 10, Part II, Applications, in: Hilbert-Huang Transform: Introduction and Applications, edited by: Huang, N., World Scientific Publishers, Singapore, 2005.

Prospero, J. M. and Nees, R. T.: Impact of the North African drought and El Nino on mineral dust in the Barbados trade winds, Nature, 320, 735-738, 1986.

Reason, C. J. C.: Subtropical Indian Ocean SST dipole events and southern African rainfall, Geophys. Res. Lett., 28(11), 22252227, 2001.

Reason, C. J. C.: Sensitivity of the southern African circulation to dipole sea-surface temperature patterns in the south Indian Ocean, Int. J. Climatol., 22(4), 377-393, 2002.

Reason, C. J. C. and Rouault, M.: ENSO-like decadal variability and South African rainfall, Geophys. Res. Lett., 29(13), 16381642, 2002.

Richard, Y., Camberlin, P., Fauchereau, N., and Mulenga, H.: Cohérence intrasaisonnière de la variabilité pluviométrique interannuelle en Afrique du Sud, L'Espace Géographique, 31, 63-72, 2002.

Rödenbeck, C., Houweling, S., Gloor, M., and Heimann, M.: $\mathrm{CO}_{2}$ flux history 1982-2001 inferred from atmospheric data using a global inversion of atmospheric transport, Atmos. Chem. Phys., 3, 1919-1964, doi:10.5194/acp-3-1919-2003, 2003.

Saji, N. H. and Yamagata, T.: Possible impacts of Indian Ocean Dipole mode events on global climate, Clim. Res., 25(2), 151169, 2003.

Saji, N. H., Goswami, B. N., Vinayachandran, P. N., and Yamagata, T.: A dipole mode in the tropical Indian Ocean, Nature, 401, 360-364, 1999.

Sellers, P. J., Mintz, Y., Sud, Y. C., and Dalcher, A.: The design of a simple biosphere model $(\mathrm{SiB})$ for use within general circulation models, J. Atmos. Sci., 43, 505-531, 1986.

Sellers, P. J., Berry, J. A., Collatz, G. J., Field, C. B., and Hall, F. G.: Canopy Reflectance, Photosynthesis, and Transpiration. 3. A Reanalysis Using Improved Leaf Models and a New Canopy Integration Scheme, Remote Sens. Environ., 42(3), 187-216, 1992.

Sellers, P. J., Tucker, C. J., Collatz, G. J., Los, S. O., Justice, C. O., Dazlich, D. A., and Randall, D. A.: A global 1-degree by 1-degree NDVI data set for climate studies. 2. The generation of global fields of terrestrial biophysical parameters from NDVI, Int. J. Remote Sens., 15(17), 3519-3545, 1994.

Sellers, P. J., Bounoua, L., Collatz, G. J., Randall, D. A., Dazlich, D. A., Los, S. O., Berry, J. A., Fung, I., Tucker, C. J., Field, C. B., and Jensen, T. G.: Comparison of radiative and physiological effects of doubled atmospheric $\mathrm{CO}_{2}$ on climate, Science, 271, 1402-1406, 1996a.

Sellers, P. J., Los, S. O., Tucker, C. J., Justice, C. O., Dazlich, D. A., Collatz, G. J., and Randall, D. A.: A revised land surface parameterization (SiB2) for atmospheric GCMs. 2. The generation of global fields of terrestrial biophysical parameters from satellite data, J. Climate, 9(4), 706-737, 1996b.

Sellers, P. J., Randall, D. A., Collatz, G. J., Berry, J. A., Field, C. B., Dazlich, D. A., Zhang, C., Collelo, G. D., and Bounoua, L.: 
A revised land surface parameterization ( $\mathrm{SiB} 2)$ for atmospheric GCMs. 1. Model formulation, J. Climate, 9(4), 676-705, 1996c.

Shannon, L. V., Boyd, A. J., Brundrit, G. B., and Taunton-Clark, J.: On the existence of an El Niño-type phenomenon in the Benguela system, J. Mar. Res., 44, 495-520, 1986.

Still, C. J., Berry, J. A., Collatz, G. J., and DeFries, R. S.: Global distribution of C-3 and C-4 vegetation: Carbon cycle implications, Global Biogeochem. Cy., 17, 1006, doi:10.1029/2001GB001807, 2003.

Tempel, P., Batjes, N. H., and van Engelen, V. W. P.: IGBP-DIS soil data set for pedotransfer function development, Working paper and Preprint 96/05, International Soil Reference and information Centre (ISRIC), Wageningen, 1996.

Todd, M. and Washington, R.: Extreme daily rainfall in southern African and Southwest Indian Ocean tropical-temperate links, S. Afr. J. Sci., 94(2), 64-70, 1998.

Tourre, Y. M., Rajagopalan, B., and Kushnir, Y.: Dominant patterns of climate variability in the Atlantic Ocean during the last 136 years, J. Climate, 12, 2285-2300, 1999.

Tourre, Y. M., Paz, S., Cassou, C., and Kutiel, H.: Atmospheric dynamics over northwest Africa and linkages with Sahelian rainfall, Geophys. Res. Lett., 33, L14808, doi:10.1029/2006GL026695, 2006.

Tucker, C. J., Pinzon, J. E., Brown, M. E., Slayback, D., Pak, E. W., Mahoney, R., Vermote, E., and El Saleous, N.: An Extended AVHRR 8-km NDVI Data Set Compatible with MODIS and SPOT Vegetation NDVI Data, Int. J. Remote Sens., 26(20), 4485-4498, 2006.

Tyson, P. D.: Temporal and spatial variation of rainfall anomalies in Africa south of latitude 22-degrees during the period of meteorological record, Climatic Change, 2(4), 363-371, 1980.

Tyson, P. D.: Climatic-change in southern Africa - Past and present conditions and possible future scenarios, Climatic Change, 18(23), 241-258, 1991.

Tyson, P. D., Cooper, G. R. J., and McCarthy, T. S.: Millennial to multi-decadal variability in the climate of southern Africa, Int. J. Climatol., 22(9), 1105-1117, 2002.

Usman, M. T., and Reason, C. J. C.: Dry spell frequencies and their variability over southern Africa, Clim. Res., 26(3), 199211, 2004.

van der Werf, G. R., Randerson, J. T., Collatz, G. J., Giglio, L., Kasibhatla, P. S., Arellano, A. F., Olsen, S. C., and Kasischke, E. S.: Continental-scale partitioning of fire emissions during the 1997 to $2001 \mathrm{El} \mathrm{Nino/La} \mathrm{Nina} \mathrm{period,} \mathrm{Science,} \mathrm{303,} \mathrm{73-76,} 2004$. van der Werf, G. R., Randerson, J. T., Giglio, L., Collatz, G. J., Kasibhatla, P. S., and Arellano Jr., A. F.: Interannual variability in global biomass burning emissions from 1997 to 2004, Atmos. Chem. Phys., 6, 3423-3441, doi:10.5194/acp-6-3423-2006, 2006.

Vidale, P. L. and Stöckli, R.: Prognostic canopy air space solutions for land surface exchanges, Theor. Appl. Climatol., 80, 245-257, 2005.

Vuille, M., Werner, M., Bradley, R. S., Chan, R. Y., and Keimig, F.: Stable isotopes in east African precipitation record Indian ocean zonal mode, Geophys. Res. Lett., 32, L21705, doi:10.1029/2005GL023876, 2005.

Webster, P. J., Moore, A. M., Loschnigg, J. P., and Leben, R. R.: Coupled ocean-atmosphere dynamics in the Indian Ocean during 1997-98, Nature, 401, 356-360, 1999.

Williams, C. A., Hanan, N. P., Neff, J. C., Scholes, R. J., Berry, J. A., Denning, A. S., and Baker, D. F.: Africa and the global carbon cycle, Carbon Balance and Management, 2(3), 1-13, doi:10.1186/1750-0680-2-3, 2007.

Williams, C. A., Hanan, N. P., Baker, I., Collatz, G. J., Berry, J., and Denning, A. S.: Interannual variability of photosynthesis across Africa and its attribution, J. Geophys. Res., 113, G04015, doi:10.1029/2008JG000718, 2008.

Wolter, K. and Timlin, M. S.: Monitoring ENSO in COADS with a seasonally adjusted principal component index, paper presented at Proceedings of the 17th Climate Diagnostics Workshop, Norman, OK, NOAA/N MC/CAC, NSSL, Oklahoma Climate Survey, CIMMS and the School of Meteorology, University of Oklahoma, 1993.

Wolter, K. and Timlin, M. S.: Measuring the strength of ENSO events - how does 1997/98 rank?, Weather, 53, 315-324, 1998.

$\mathrm{Wu}, \mathrm{R}$. and Kirtman, B. P.: Impacts of the Indian Ocean on the Indian Summer Monsoon-ENSO Relationship, J. Climate, 17, 3037-3054, 2004.

Yamagata, T., Behera, S. K., Rao, S. A., Guan, Z. Y., Ashok, K., and Saji, H. N.: Comments on "Dipoles, temperature gradients, and tropical climate anomalies”, B. Am. Meteorol. Soc., 84(10), 1418-1422, 2003.

Zebiak, S. E.: Air-sea interaction in the equatorial Atlantic region, J. Climate, 6, 1567-1586, 1993.

Zinke, J., Dullo, W. C., Heiss, G. A., and Eisenhauer, A.: ENSO and Indian Ocean subtropical dipole variability is recorded in a coral record off southwest madagascar for the period 1659 to 1995 , Earth Planet. Sc. Lett., 228, 177-194, 2004. 